\title{
Uptake of Organic Matter by Meiofauna Organisms and Interrelationships with Bacteria*
}

\author{
L.-A. Meyer-Reil ${ }^{1}$ and A. Faubel ${ }^{2}$ \\ ${ }^{1}$ Institut für Meereskunde an der Universität Kiel, Düsternbrooker Weg 20, 2300 Kiel 1, Federal Republic of Germany \\ ${ }^{2}$ Zoologisches Institut und Museum der Universität Hamburg, Martin-Luther-King-Platz 3, 2000 Hamburg 13, Federal Republic \\ of Germany
}

\begin{abstract}
Investigations of bacteria and meiofauna in sandy beach sediments of the brackish-water Kiel Fjord and Kiel Bight (Baltic Sea, FRG) indicate inverse interrelationships: high numbers and biomass (carbon) of meiofauna are correlated with low numbers and biomass of bacteria, and vice versa. Bacterial carbon is 4 times as high as meiofauna carbon; this reflects the extreme ecological character of the wave-washed beach sediments studied. Tracer experiments using tritiated glucose reveal different participation of individual groups of meiofauna in the incorporation of labelled material. Oligochaetes (exclusively detritovores) show the highest incorporation rate of organic material, followed by turbellarians and nematodes. There is some indication that particulate organic matter originally derived from bacteria and that their extracellular products represented the major part of the organic material taken up. Laboratory experiments stress the necessity of studying meiofauna activity under close-to-natural conditions.
\end{abstract}

\section{INTRODUCTION}

Detritus is of vital importance for the nutrition of meiofauna organisms in sediments (Giere, 1975; Tenore, 1977; Gerlach, 1978; Briggs et al., 1979). As has been documented in Volume II of 'Marine Ecology' (see also Fenchel, 1970; Hargrave, 1970; and other authors cited there), detritus itself plays a minor role, whereas bacteria attached to detritus are the major food source for detritus feeders. This is understandable considering the high biomass and productivity of bacteria on the surface of detritus particles (Weise and Rheinheimer, 1978; Meyer-Reil et al., 1980). A number of reports have been published showing the nutritional specialization of meiofauna organisms studied under laboratory conditions (e. g. Gray, 1967; Lee et al., 1976; Tietjen and Lee, 1977; Rieper, 1978). Besides particulate organic matter (bacteria and their extracellular products), marine invertebrates obviously can take up dissolved organic substances (e. g. Southward and Southward, 1971; Schlichter, 1974). However, as already mentioned by Ernst and Goerke (1969), the participation of bacteria in the

\footnotetext{
- Publication No. 273 of the "Joint Research Program" at Kiel University (Sonderforschungsbereich 95 der Deutschen Forschungsgemeinschaft)
}

uptake of dissolved organic substances by marine invertebrates is difficult to evaluate. Working with an axenic nematode, Tietjen and Lee (1975) found it unlikely that dissolved organic substances represent a major nutrient source for the animals studied.

It is obvious from the literature that information is needed on interactions between bacteria and meiofauna in the field, as well as on the participation of different groups of meiofauna in the uptake of organic material. Hence we have studied sandy beach sediments of the brackish-water Kiel Fjord and Kiel Bight (Baltic Sea; FRG) and examined the activity of meiofauna organisms under different environmental conditions in the laboratory.

\section{MATERIALS AND METHODS}

Sampling was carried out at 9 stations in sandy beach sediments of the brackish Kiel Fjord and Kiel Bight (Western Baltic Sea; FRG) during the periods July 4-13, 1977, and November 6-11, 1978. The location of the stations is illustrated in Figure 1 (for details consult Meyer-Reil et al., 1980). As sampling area, locations next to the shore line were chosen where the sediments were subjected to brief periods of exposure to brackish water and air, respectively. For meiofauna 


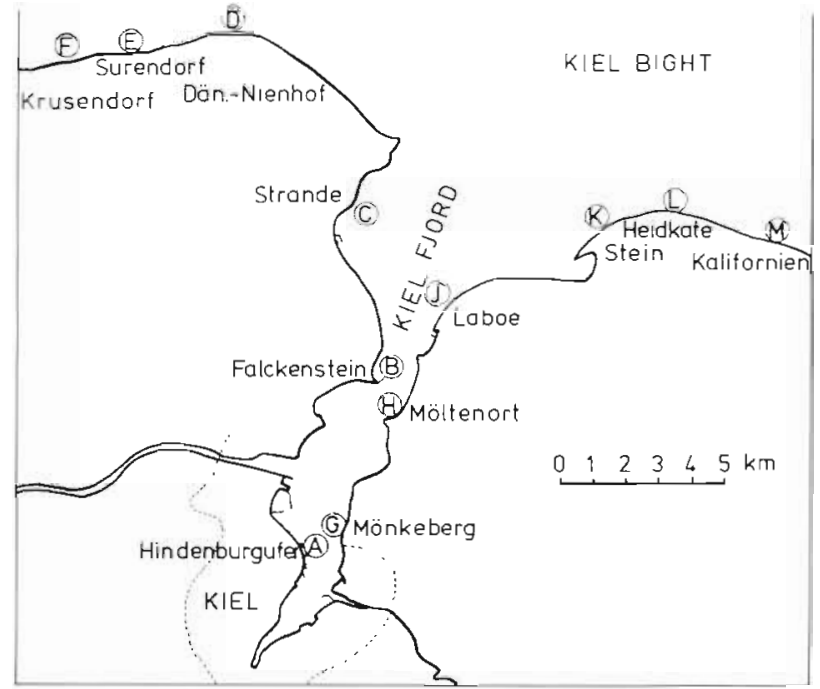

Fig. 1. Sampling stations at Kiel Fjord and Kiel Bight (Baltic Sea; FRG). From the stations represented, Stations $A, C, E, F$, $G, H, K, L, M$ were investigated for bacteria and meiofauna. (After Meyer-Reil et al., 1980)

investigations, sediment cores $(0-2 \mathrm{~cm}$ horizon) were collected in plastic tubes $(5 \mathrm{~cm}$ diameter). In the laboratory, the meiofauna was carefully separated from the sediment by elutriation without fixation of the samples. Protozoans were not considered. Meiofauna carbon was determined in a CHN-Analyser $185 \mathrm{~B}$ (Hewlett-Packard). Number and biomass of bacteria were analysed by epifluorescence microscopy (MeyerReil et al., 1978) in sediment cores withdrawn in plastic syringes $(1.6 \mathrm{~cm}$ diameter; top cut off; sediment depth $0-1 \mathrm{~cm})$.

For determining incorporation of labelled material in meiofauna, undisturbed sediment cores were collected in plastic tubes as described above. The samples were withdrawn $n_{t}$ and a piston made of teflon was inserted from the bottom side of the sampling tube. The teflon piston set free an opening in the center part connected to a stainless steel tube. The central opening is equipped with a glass-sintered disc and a cellulose nitrate membrane (Sartorius Membranfilter Gesellschaft) on top. Thus the syringe serves as a small filtration unit (see below).

Sediment cores were processed in the laboratory within $1 \mathrm{~h}$ after sampling. The plastic tubes were mounted onto a rack connected with a pump. To each of the cores, $10 \mathrm{ml}$ of natural seawater (filter-sterilized) from the corresponding station was added. The seawater was spiked with $20 \mu \mathrm{l}$ of D- $\left[1-{ }^{3} \mathrm{H}\right]$ glucose $(2 \mu \mathrm{Ci}$ $\mathrm{ml}^{-1}$; specific activity $9.9 \mathrm{Ci} \mathrm{mmol}^{-1}$; Amersham Buchler Co.). For a few seconds, low vacuum was applied $\left(0.2 \mathrm{kPa} \mathrm{cm}^{-2}\right)$ to substitute the interstitial water originally present in the sediment cores by seawater spiked with labelled glucose. The cores were incubated at in situ temperature in the dark for different periods of time. Cores fixed at time zero and incubated as described served as controls. Two fixatives were compared: formalin (4\%) and Bouin fixation $(15 \mathrm{ml}$ of picrinic acid, $5 \mathrm{ml}$ of formalin, $1 \mathrm{ml}$ of glacial acetic acid). After incubation, the sediment cores were transferred into glass flasks, fixed (see above) and carefully washed several times with seawater. Using binocular microscopes, individual meiofauna components were determined, counted and transferred onto cellulose nitrate membranes and dried in an oven at $60^{\circ} \mathrm{C}$. Parallel to this, aliquots of seston material $(25 \mathrm{ml}$ ), withdrawn after sedimentation of coarse sand grains, were pipetted onto filters and dried as described.

Additional experiments were carried out with the turbellarian Haplogonaria syltensis (Dörjes, 1968) and the archiannelid Trilobodrilus axi (Westheide, 1967), the dominating species in different horizons of sandy beach sediments at List beach (Island of Sylt, North Sea; FRG). The ecology of the species was investigated in detail by Schmidt (1968) and Faubel (1974, 1976, 1977). The organisms were carefully separated from the sediment and pipetted into a series of glass flasks containing (1) $20 \mathrm{ml}$ of natural seawater, (2) $20 \mathrm{ml}$ of natural seawater with $1 \mathrm{~g}$ of sediment added (the meiofauna was removed except for protozoans), and (3) $20 \mathrm{ml}$ of natural seawater with $1 \mathrm{~g}$ of sterile sediment (combusted at $550^{\circ} \mathrm{C}$ ). To each of the flasks, $20 \mu \mathrm{l}$ of ${ }^{3} \mathrm{H}$-glucose (see above) was pipetted. Samples including controls were incubated at in situ temperature and processed as described.

Dry filters carrying the organisms were combusted in a Tri-Carb Sample Oxidizer (Packard Instrument) for 2 min. Radioactivity was determined in $12 \mathrm{ml}$ Monophase-40 (Packard Instrument) in a liquid scintillation counter (Betazint 5000; Berthold and Frieseke). Samples were corrected for control counts.

\section{RESULTS AND DISCUSSION}

Indications of interrelationships between bacteria and meiofauna were obtained from number and biomass of the two groups of organisms at sandy beach sediments of the Kiel Fjord and the Kiel Bight (Fig. 1). Seven stations were sampled at two seasons of the year; two stations only once. A plot of bacterial carbon $\mathrm{cm}^{-2}$ (sediment depth $0-1 \mathrm{~cm}$ ) against meiofauna carbon $\mathrm{cm}^{-2}$ (sediment depth $0-2 \mathrm{~cm}$ ) is shown in Figure 2. A corresponding illustration is obtained by numerical plotting of bacteria against meiofauna. Figure 2 reveals inverse relationships between bacteria and meiofauna. High numbers and biomass values of bacteria correlate with low numbers and biomass values of 


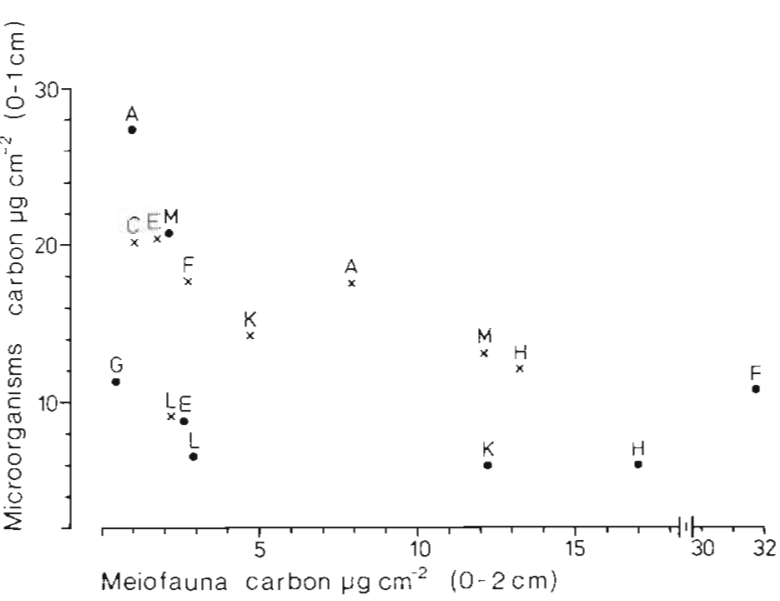

Fig. 2. Relation of bacterial carbon to meiofauna carbon. Crosses: stations sampled in July 1977 ; dots: stations sampled in November 1978. For localization of sampling stations see Figure 1

meiofauna and vice versa. For July samples, interrelations are more distinct than for November samples, where number and biomass of both groups of organisms show a broader variation.

The average values for bacterial and meiofauna carbon are $14.0 \mu \mathrm{g} \mathrm{cm}^{-2}$ (sediment depth $0-1 \mathrm{~cm}$ ) and 7.3 $\mu \mathrm{g} \mathrm{cm}{ }^{-2}$ (sediment depth $0-2 \mathrm{~cm}$ ), respectively. If we extrapolate bacterial carbon down to a depth of $2 \mathrm{~cm}$ (assuming even distribution throughout the $0-2 \mathrm{~cm}$ horizon), bacterial carbon would be 4 times as high as meiofauna carbon. This is understandable from the specific location of the sampling sites. At the beach sediments sampled, wave action causes permanent movement in the uppermost sediment layer (approximately $0-0.5 \mathrm{~cm}$ ). Organisms not firmly attached to sediment particles will be washed out quickly. This applies especially to meiofauna organisms, whereas bacteria firmly fixed to particles (cf. Meadows and Anderson, 1966; Meyer-Reil et al., 1978) are well protected. This specific situation in beach sediments might be responsible for the high carbon ratio bacteria to meiofauna found during this investigation. For subtidal sediments, however, Gerlach (1978, his Table 3, page 60 ; corrected values) reported equal amounts of bacterial and meiofauna carbon.

Subsequent experiments were carried out by incubating sediment cores with labelled dissolved organic solute $\left({ }^{3} \mathrm{H}\right.$-glucose). After predetermined periods, meiofauna and aliquots of seston material were removed and their relative activity determined. While the activity associated with seston decreased, meiofauna activity increased (Fig. 3; Station Falckenstein, Kiel Fjord, FRG; October 23, 1979). This increase seems to be linear during the 24 -h incubation period. Since the values were corrected for abiotic adsorption, the variations of cpm reflect biological activities.
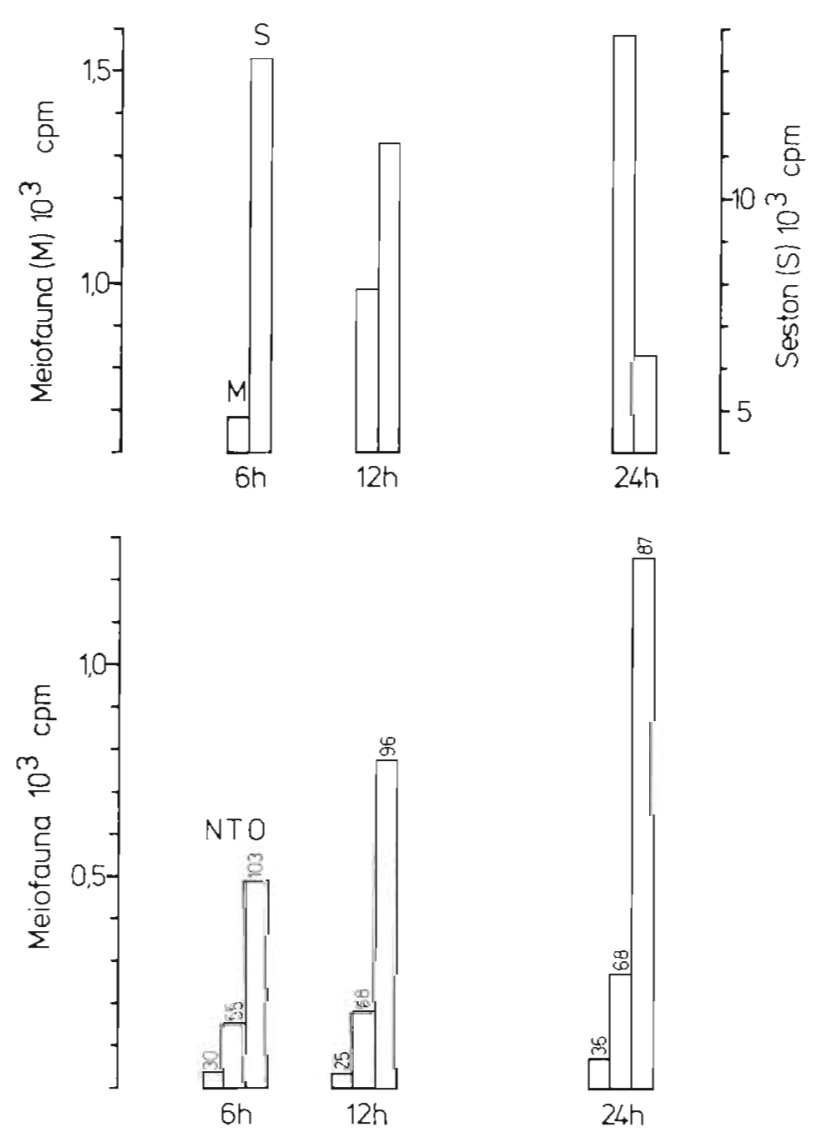

Fig. 3. Fate of labelled organic material. Upper: Uptake by meiofauna (M) and association with seston (S). Lower: Uptake by nematodes $(N)$, turbellarians $(T)$ and oligochaetes $(O)$. Numbers on top of columns: individuals sample ${ }^{-1}$. Parallel samples were incubated with ${ }^{3} \mathrm{H}$-glucose for 6,12 or $24 \mathrm{~h}$

(Station Falckenstein, Kiel Fjord, FRG; October 23, 1979)

Generally two routes are conceivable for the incorporation of dissolved organic matter by meiofauna: uptake of dissolved organic material (in our example ${ }^{3} \mathrm{H}$-glucose) and/or particulate organic matter via bacteria and their extracellular products (slime, sheets, etc.). In the latter case, bacteria would have taken up ${ }^{3} \mathrm{H}$-glucose and converted it into labelled bacterial biomass, which then would have been consumed by meiofauna. From measurements of bacterial activity in beach sediments, rapid uptake and incorporation of glucose by bacteria could be documented (Meyer-Reil et al., 1978). The decrease in the activity associated with seston (Fig. 3) cannot be explained by bacterial respiration and release of bacterial cells alone. A considerable loss of activity originally associated with seston is obviously caused by meiofauna grazing (cf. experiments described below). This seems to indicate that the major part of labelled material taken up by meiofauna under natural conditions is particulate organic matter originally derived trom bacteria (e. g. 
cells, slime layers); these densely colonize the surface of sand grains and detritus material (Rhoads, 1974; Weise and Rheinheimer, 1978).

There are several reports in the literature on the importance of dissolved organic substances for the nutrition of marine invertebrates. The experiments by Southward and Southward $(1970,1971)$ with pogonophores and other marine animals were carried out in seawater filtered through Whatman GF/C filters (average pore size: $0.8-1.0 \mu \mathrm{m}$ ), which allow a high percentage of bacteria (in the Baltic Sea ca. $50 \%$ ) to pass. Schlichter (1974) incubated Anemonia sulcata in artificial seawater. However, the potential participation of body-attached bacteria in the uptake of dissolved organic matter is difficult to evaluate (Ernst and Goerke, 1969). Working with axenic cultures of the nematode Rhabditis marina, Tietjen and Lee (1975) found that dissolved organic substances play no significant role in the nematode's nutrition. As long as a bacterial intermediary cannot be excluded, the importance of dissolved organic substances as a major nutrient supply for marine invertebrates must remain doubtful.

Fixation greatly influences the retention of labelled material in meiofauna organisms, a phenomenon which is well known for the retention of label within bacteria. Generally, fixation with Bouin solution (see Materials and Methods) yield a 5-fold higher retention of labelled material by meiofauna compared to fixation with formalin. The lower retention of material following formalin fixation could be due to loss of lowmolecular weight material caused by an alteration in the permeability of the cell walls. Consequently, Bouin fixation was used in subsequent experiments.

In order to determine the degree of variability in the uptake of labelled material by meiofauna organisms, 3 parallel samples and a control were incubated for 13.5 h (Station Falckenstein; August 29, 1979). The samples were fixed and individual components of meiofauna separated according to the dominating systematical groups (oligochaetes, turbellarians, nematodes). As can be seen from Table 1, the amount of labelled material retained by individual organisms of the different meiofauna groups (expressed per 100 individuals) is comparable. Furthermore, the dominating role of oligochaetes in the incorporation of organic material becomes obvious (see below).

Detailed experiments were carried out to determine the amount of labelled material taken up by different meiofauna groups. Since oligochaetes, turbellarians and nematodes represent more than $95 \%$ of the meiofauna at the stations investigated, only these groups were considered. Samples were incubated with ${ }^{3} \mathrm{H}$-glucose (see Materials and Methods) for different periods of time, fixed, washed, and the above mentioned groups separated. The results are illustrated in Figure 3 (Station Falckenstein; October 23, 1979). Oligochaetes, turbellarians and nematodes generally show linear uptake of labelled matter with time. The total amount of activity retained increases while the activity associated with seston decreases. Oligochaetes play the dominating role in the incorporation of labelled organic material, followed by turbellarians and nematodes. This does not simply reflect their relative abundance (oligochaetes are most abundant, followed by turbellarians and nematodes; Fig. 3). A corresponding situation results when activity is related to equal numbers of meiofauna organisms. However, relating activity to equal amounts of meiofauna biomass produces different results. Again, oligochaetes (average biomass: $2.0 \mu \mathrm{g}$ dry weight ind.$^{-1}$ ) show the highest activity, whereas equal amounts of turbellarians and

Table 1. Uptake of labelled organic material by meiofauna organisms. S1-S3: parallel samples. All samples incubated with ${ }^{3} \mathrm{H}-$ glucose for 13.5 h (Station Falckenstein, Kiel Fjord, FRG; August 29, 1979). C: controls, fixed in Bouin fixative prior to ${ }^{3} \mathrm{H}-g$ lucose addition. Uptake activity is expressed as counts $\mathrm{min}^{-1}(\mathrm{cpm})$

\begin{tabular}{|c|c|c|c|c|c|c|}
\hline Group & Sample & $\begin{array}{l}\text { Individuals } \\
\text { (No.) }\end{array}$ & cpm & $\begin{array}{l}\text { ivity } \\
\text { cpm } 100 \text { ind. }^{-1}\end{array}$ & $\begin{array}{l}\text { Average } \\
\text { (S1-S3) }\end{array}$ & $\begin{array}{c}\text { Average minus } \\
\text { control }(\mathrm{C})\end{array}$ \\
\hline \multirow{4}{*}{ Oligochaetes } & S1 & 19 & 1.203 & 6.332 & \multirow[t]{4}{*}{5.805} & \multirow[t]{4}{*}{4.381} \\
\hline & $\mathrm{S} 2$ & 9 & 485 & 5.389 & & \\
\hline & S3 & 15 & 854 & 5.693 & & \\
\hline & $\mathrm{C}$ & 17 & 242 & 1.424 & & \\
\hline \multirow{4}{*}{ Turbellarians } & $\mathrm{S} 1$ & 18 & 85 & 472 & \multirow[t]{4}{*}{460} & \multirow[t]{4}{*}{241} \\
\hline & $\mathrm{S} 2$ & 11 & 37 & 336 & & \\
\hline & S3 & 14 & 80 & 571 & & \\
\hline & $\mathrm{C}$ & 16 & 35 & 219 & & \\
\hline \multirow{4}{*}{ Nematodes } & $\mathrm{S} 1$ & 89 & 241 & 271 & \multirow[t]{4}{*}{273} & \multirow[t]{4}{*}{148} \\
\hline & $\mathrm{S} 2$ & 37 & 120 & 324 & & \\
\hline & S3 & 48 & 107 & 223 & & \\
\hline & C & 53 & 66 & 125 & & \\
\hline
\end{tabular}


nematodes (average: 1.8 and $0.8 \mu \mathrm{dry}$ weight ind. ${ }^{-1}$ ) reveal similar rates of uptake. Comparable results were obtained from two other experiments carried out at the same location (Station Falckenstein; August 25 and 29,1979 ).

The different modes of incorporation by the different groups of meiofauna organisms can be related to differences in nutrition. Oligochaetes are detritovores, turbellarians omnivores, and nematodes partly detritovores and partly predators. Apparently, the major part of incorporated activity was taken up as particulate organic matter via bacteria and their extracellular products (see above). The vital importance of particulate organic matter (bacteria) for the nutrition of marine invertebrates is well documented (e. g. Fenchel, 1970; Hargrave, 1970; Pfaffenhöfer and Strickland, 1970). Detritus itself seems to play a less important role.

While most samples were taken in the morning (9:00 a.m.), during one experiment (Station Falckenstein; October 23, 1979), additional samples were obtained in the afternoon (5:00 p.m.). There were no measurable differences in wave action and temperature between samplings. All of the three groups (oligochaetes, turbellarians, nematodes) show higher incorporation of labelled material than in the morning samples. While this indicates diurnal variations, a phenomenon already documented for bacterial activity (Meyer-Reil et al., 1979), further experiments are necessary before definite conclusions can be drawn.

Preliminary experiments were carried out to determine rates of labelled material uptake by meiofauna organisms under different environmental conditions. Haplogonaria syltensis (Turbellaria) and Trilobodrilus axi (Archiannelida) were incubated for $6 \mathrm{~h}$ in a series of flasks containing natural seawater (filter sterilized) and ${ }^{3} \mathrm{H}$-glucose. To two of the series, natural sediment or sterile sediment (combusted) were added (Table 2; List beach; October 7, 1979). Both organisms show maximum activity (in terms of ${ }^{3} \mathrm{H}$-glucose bound or taken up) after incubation in seawater; addition of sterile sediment drastically reduces the activity by a factor of 10 . In natural sediment, the activity is further reduced by a factor of 1.5 . These differences seem to be related to different locomotory behaviour: in sterile seawater, the organisms continuously crawl around on the bottom of the flasks apparently in search of sediment. Under these unnatural conditions of increased activity, higher amounts of labelled organic material are bound or taken up.

Our experiments do not reveal whether the organic matter is bound to the outside or incorporated into the animals' bodies. We also do not know whether the binding or the uptake is directly or indirectly (e.g. via slime production) related to stress conditions. Apparently most affected by the stress, Haplogonaria syltensis exhibits much higher activity than Trilobodrilus axi. Sterile seawater plus sterile sediment appeared to greatly reduce the stress, but the locomotory activity is still higher than in natural sediment. This may be due to lack of natural organic material and/or changes in the structure of the sediment following combustion. Like all other experiments, this experiment was repeated twice with similar results. The considerable differences in the uptake of organic material by animals under different levels of stress underline the need for studying meiofauna activities under close-tonatural conditions. Only here can we expect ecologically valid data.

Table 2. Haplogonaria syltensis and Trilobodrilus axi. Uptake of labelled organic material by individuals incubated for 6 h in natural seawater (filter sterilized) with ${ }^{3} \mathrm{H}$-glucose. In addition to this, samples contained: $\mathrm{S} 1=1 \mathrm{~g}$ of natural sediment (meiofauna removed); $\mathrm{S} 2=1 \mathrm{~g}$ of sterile sediment (combusted); $\mathrm{S} 3=$ untreated sample. C1-C3: controls. Uptake activity is expressed as counts min $^{-1}(\mathrm{cpm})$. Station List beach, Island of Sylt, North Sea, FRG; October 7, 1979

\begin{tabular}{|c|c|c|c|c|c|}
\hline \multirow[t]{2}{*}{ Species } & \multirow[t]{2}{*}{ Sample } & \multirow{2}{*}{$\begin{array}{l}\text { Individuals } \\
\text { (No.) }\end{array}$} & \multicolumn{2}{|c|}{ Activity } & \multirow{2}{*}{$\begin{array}{l}\text { cpm sample minus } \\
\text { cpm control (C) }\end{array}$} \\
\hline & & & $\mathrm{cpm}$ & $\begin{array}{l}\text { cpm } 100 \\
\text { ind. }^{-1}\end{array}$ & \\
\hline \multirow{6}{*}{$\begin{array}{l}\text { Haplogonaria } \\
\text { syltensis }\end{array}$} & S1 & 100 & 1.047 & 1.047 & \multirow[t]{2}{*}{928} \\
\hline & $\mathrm{C} 1$ & 150 & 179 & 119 & \\
\hline & $\mathrm{S} 2$ & 86 & 1.833 & 2.131 & \multirow[t]{2}{*}{1.514} \\
\hline & $\mathrm{C} 2$ & 83 & 512 & 617 & \\
\hline & S3 & 100 & 17.029 & 17.029 & \multirow[t]{2}{*}{14.715} \\
\hline & $\mathrm{C} 3$ & 200 & 4.628 & 2.314 & \\
\hline \multirow{6}{*}{ Trilobodrilus axi } & S1 & 200 & 807 & 404 & \multirow[t]{2}{*}{352} \\
\hline & $\mathrm{C} 1$ & 200 & 103 & 52 & \\
\hline & $\mathrm{S} 2$ & 190 & 1.143 & 602 & \multirow[t]{2}{*}{532} \\
\hline & $\mathrm{C} 2$ & 90 & 63 & 70 & \\
\hline & S3 & 200 & 13.801 & 6.901 & \multirow[t]{2}{*}{6.800} \\
\hline & $\mathrm{C} 3$ & 200 & 202 & 101 & \\
\hline
\end{tabular}


Autoradiography seems to be the method of choice for further analysis of some of the problems raised in this paper. Present autoradiographic experiments intend to follow the route of labelled material into the organisms studied.

Acknowledgement. We thank U. Kaiser for valuable assistance.

\section{LITERATURE CITED}

Briggs, K. B., Tenore, K. R., Hanson, R. B. (1979). The role of microfauna in detrital utilization by the polychaete, Nereis succinea (Frey and Leuckart). J. exp. mar. Biol. Ecol. 36: 225-234

Dörjes, J. (1968). Die Acoela (Turbellaria) der deutschen Nordseeküste und ein neues System der Ordnung. Z. zool. Syst. Evolutionsforsch. 6: 56-452

Ernst, W., Goerke, H. (1969). Aufnahme und Umwandlung gelöster Glucose- ${ }^{14} \mathrm{C}$ durch Lanice conchilega (Polychaeta, Terebellidae). Veröff. Inst. Meeresforsch. Bremerhaven 11: 313-326

Faubel, A. (1974). Die Acoela (Turbellaria) eines Sandstrandes der Nordseeinsel Sylt. Mikrofauna Meeresboden 32: $1-58$

Faubel, A. (1976). Populationsdynamik und Lebenszyklen interstitieller Acoela und Macrostomida (Turbellaria). Mikrofauna Meeresboden 56: 1-107

Faubel, A. (1977). Distribution of Acoela and Macrostomida (Turbellaria) in the littoral of the North Frisian Islands Sylt, Romö, Jordsand, and Amrum (North Sea). Senckenbergiana marit. 9: 59-74

Fenchel, T. (1970). Studies on the decomposition of organic detritus derived from the turtle grass Thalassia testudinum. Limnol. Oceanogr. 15: 14-20

Gerlach, S. A. (1978). Food-chain relationships in subtidal silty sand marine sediments and the role of meiofauna in stimulating bacterial productivity. Oecologia (Berl.) 33: 55-69

Giere, O. (1975). Population structure, food relations and ecological role of marine oligochaetes, with special reference to meiobenthic species. Mar. Biol. 31: 139-156

Gray, J. S. (1967). Substrate selection by the archiannelid Protodrilus hypoleucus Armenante. J. exp. mar. Biol. Ecol. 1: $47-54$

Hargrave, B. T. (1970). The effect of a deposit-feeding amphipod on the metabolism of benthic microflora. Limnol. Oceanogr. 15: 21-30

Lee, J, J., Tenore, K. R., Tietjen, J. H., Mastropaolo, C. (1976). An experimental approach toward understanding the role of meiofauna in a detritus-based marine food web. In: Cushing, C. E. (ed.) Proceedings of the 4th National Symposium Radioecology and Energy Resources. Dowden, Hutchinson and Ross, Stroudsburg, Pa. pp. 140-147

Meadows, P. S., Anderson, J. G. (1966). Micro-organisms attached to marine and freshwater sand grains. Nature, Lond. 212: 1059-1060

Meyer-Reil, L.-A., Dawson, R., Liebezeit, G., Tiedge, H. (1978). Fluctuations and interactions of bacterial activity in sandy beach sediments and overlying waters. Mar. Biol. 48: $161-171$

Meyer-Reil, L.-A., Bölter, M., Liebezeit, G., Schramm, W (1979). Short-term variations in microbiological and chemical parameters. Mar. Ecol. Prog. Ser. 1: 1-6

Meyer-Reil, L.-A., Bölter, M., Dawson, R., Liebezeit, G., Szwerinski, H., Wolter, K. (1980). Interrelationships between microbiological and chemical parameters of sandy beach sediments, a summer aspect. Appl. environ. Microbiol. 39: 797-802

Paffenhöffer, G.-A., Strickland, J. D. H. (1970). A note on the feeding of Calanus helgolandicus on detritus. Mar. Biol. 5: 97-99

Rhoads, D. C. (1974). Organism-sediment relations on the muddy sea floor. Oceanogr. Mar. Biol. Ann. Rev. 12: 263-300

Rieper, M. (1978). Bacteria as food for marine harpacticoid copepods. Mar. Biol. 45: 337-345

Schlichter, D. (1974). Meerwasser als Nahrungsquelle: Aufnahme gelöster organischer Verbindungen. Sonderdruck Verhandlungen der Gesellschaft für Ókologie, Saarbrücken 1973, pp. 25-38

Schmidt, P. (1968). Die quantitative Verteilung und Populationsdynamik des Mesopsammons am GezeitenStrand der Nordseeinsel Sylt. I. Faktorengefüge und biologische Gliederung des Lebensraumes. Int. Revue ges. Hydrobiol. 53: 723-779

Southward, A. J., Southward, E. C. (1970). Observations on the role of dissolved organic compounds in the nutrition on benthic invertebrates. Experiments on three species of Pogonophora. Sarsia 45; 69-96

Southward, A. J., Southward, E. C. (1971). Observations on the role of dissolved organic compounds in the nutrition of benthic invertebrates. II. Uptake by other animals living in the same habitat as Pogonophores and by some littoral Polychaeta. Sarsia 48: 61-70

Tenore, K. R. (1977). Food chain pathways in detrital feeding benthic communities: a review, with new observations on sediment resuspension and detrial recycling. In: Coull, B. C. (ed.) Ecology of marine benthos. University of South Carolina Press, Columbia, pp. 37-53

Tietjen, J. H. Lee, J. J. (1975). Axenic culture and uptake of dissolved organic substances by the marine nematode, Rhabditis marina Bastian. Cah. Biol. Mar. 16: 685-694

Tietjen, J. H., Lee, J. J. (1977). Feeding behaviour of marine nematodes. In: Coull, B. C. (ed.) Ecology of marine benthos. University of South Carolina Press, Columbia, pp. 21-35

Weise, W., Rheinheimer, G. (1978). Scanning electron microscopy and epifluorescence investigation of bacterial colonization of marine sand sediments. Microb. Ecol. 4: 175-188

Westheide, W. (1967). Die Gattung Trilobodrilus (Archiannelida, Polychaeta) von der deutschen Nordseeküste. Helgoländer wiss. Meeresunters. 16: 207-215 